\title{
Utilization of Aseptic Seedling Explants For In vitro Propagation of Indian Red Wood
}

\author{
Kishore K CHIRUVELLA ${ }^{1,2 *}$,Arifullah MOHAMMED ${ }^{2,3}$, Rama Gopal GHANTA $^{2}$ \\ ${ }^{1 *}$ Department of Molecular Biosciences, Stockholm University, Sweden; drkishorekumaar gmail.com ( ${ }^{*}$ corresponding author) \\ ${ }^{2}$ Division of Plant Tissue Culture, Department of Botany, Sri Venkateswara University, Tirupati, Andhra Pradesh, India; ghantargopal@yahoo.co.in \\ ${ }^{3}$ Faculty of Agrobased Industry, Universiti Malaysia Kelantan, Jeli Campus, Locked bag-100, Jeli, Kelantan, Malaysia; arifullahmd@gmail.com
}

\begin{abstract}
Micropropagation has been advocated as one of the most viable biotechnological tool for ex situ conservation of rare, endangered endemic medicinal plants germplasm. Rapid clonal micropropagation protocol for large-scale multiplication of an endemic medicinal plant Soymida febrifuga (Meliaceae) was established from 15-day aseptic seedling cotyledonary node and shoot tip explants. High frequency of sprouting and shoot differentiation was observed from cotyledonary node explants compared to shoot tip, on Murashige and Skoog (MS) medium fortified with BA, KN, 2-iP and CM. Of the cytokinins used, BA $\left(3.0 \mathrm{mgl}^{-1}\right)$ supported highest average number and maximum multiple shoot differentiation (16.6). In vitro proliferated shoots were multiplied rapidly by culturing nodal segments as microcuttings, further subcultured on the same media for elongation. Elongated shoots upon transfer to MS medium fortified with IBA showed rooting within two weeks of culture. Rooted plantlets were successfully hardened and 75\% of rooted shoots successfully survived on establishment to the soil. Plants looked healthy with no visually detectable phenotypic variations. This protocol provides a successful and rapid technique that can be used for ex situ conservation minimizing the pressure on wild populations and contributes to the conservation of this endemic medicinally potent flora.
\end{abstract}

Keywords: cotyledonary node, multiple shoots, necrosis, shoot tip, Soymida

Abbreviations: BA - 6, Benzyladenine, CM - Coconut Milk, 2-iP - 2-isopentynyl Adenine, IBA - Indole 3 Butyric Acid, IAA - Indole 3 Acetic Acid, KN-kinetin, MS - Murashige and Skoog, WPM-woody plant medium, B5Gamborg medium

\section{Introduction}

The mahogany (Meliaceae) family comprises more than 50 genera and approximately $18 \%$ species are endemic to peninsular India. Soymida febrifuga A. Juss (Roxb.) (Meliaceae) commonly called as Indian red wood is a monotypic genus endemic to India (Wealth of India, 1952). Bark of this plant is used in ayurveda for credited with astringent, antiperiodic properties (Yoganarasimhan, 1996) as well adapted for gargles, vaginal infections, enemata, rheumatic swellings and also used in the treatment of diarrhoea, dysentery and fevers (Chopra et al., 1956). The decoction of the bark is antimalarial (Kirtikar and Basu, 2003), antiinflammatory (Diwan and Singh, 1993) and antiplasmodial (Simonsen et al., 2001) in action. The wood makes high quality furniture with the appearance of mahogany employed for frames, stiles and also a potential source of indigenous tanning material, gum and fiber (Anonymous, 1952). We recently reported isolation of secondary metabolites such as methyl angolensate from callus cultures of Soymida febrifuga (Chiruvella et al., 2007) displaying wide spectrum of anticancer activity (Chiruvella et al., 2008).

Conventionally propagation of Soymida febrifuga through stem cuttings is cumbersome that restricts propa- gation due to difficulty in rooting (Anonymous, 1952). Nonetheless propagation through seeds, have low germination capacity and seedlings are more prone to insect attack. Successful regeneration of plant In vitro has been reported for several meliaceous members (Ahuja, 1993; Pradhan et al., 1998; Naik et al., 2000; Seema and Jaiswal, 2002). Most of the studies carried out by others on tree species have utilised seeds and juvenile tissue than the tissue from mature plant (Bonga, 1987). Juvenile explants have been extensively employed for the clonal propagation of woody plants (Ahuja, 1993). The large scale propagation of plants by tissue culture widely spread and the number of plants species, which can be multiplied by this technique has been steadily increasing (Bhojwani and Razdan 1983).

Application of plant tissue culture technique for ex situ conservation of Soymida febrifuga for the availability throughout the year has become indispensable due to its immense medicinal importance as cited above. Although successful regeneration of Soymida febrifuga using mature nodal explants has been reported by our group (Chiruvella et al., 2011), no study utilizing In vitro aseptic seedlings explants has been reported. Here we report In vitro propagation protocol established from 15-day aseptic seedling 
using cotyledonary node and shoot tip explants. Our results demonstrate BA supported the high frequency of shoot regeneration from cotyledonary node compared to shoot tip explants. Elongated shoots were rooted on MS medium fortified with IBA. Rooted shoots (75\%) successfully survived on establishment to the soil.

\section{Materials and methods}

\section{Establishment of aseptic seedlings}

Fruits collected from the wild populations at Divyaramam nursery, Tirupati, A.P, India were air dried and stored in brown paper bags until the experiments were initiated. Prior to use, seeds were washed with 5\% teepol solution for $15 \mathrm{~min}$ and rinsed with tap water and than with sterile double distilled water. Surface sterilization was carried out by immersing the explants in $0.05 \% \mathrm{HgCl} 2$ for $15 \mathrm{~min}$ followed by 3-4 rinses in sterilized distilled water. Seeds were germinated in MS medium containing $1 \%$ and 1.5 $\%$ sucrose under aseptic conditions. Different explants like shoot tips, cotyledonary nodes, cotyledons, nodes, leaves, hypocotyl and root segments were excised from 15 day aseptic seedlings, and these were cultured on selected media to assess their morphogenic responses.

\section{Medium and culture conditions}

Initial experiments were designed for the selection of most appropriate explant and suitable medium. MS medium with different concentrations $\left(0.5-5.0 \mathrm{mg} \mathrm{l}^{-1)}\right.$ and combinations of cytokinins (BA, CM, 2-iP, TDZ and Kinetin) and auxins (IAA and NAA) were used to study their effects on shoot induction and multiplication at varying concentrations, either singly or in combination for multiple shoot production. The media were congealed with agar $(0.8 \%)$, and sucrose $3 \%$ was used as a source of carbohydrate. The $\mathrm{pH}$ of the media was adjusted to 5.8 before autoclaving at $121^{\circ} \mathrm{C}$ for $15 \mathrm{~min}$. All cultures were incubated at $25 \pm 2^{\circ} \mathrm{C}$ under $16^{\text {th }}$ photoperiod with light supplemented by cool white fluorescent tubes $(25 \mu$ moles $\left.\mathrm{m}^{-2} \mathrm{~s}^{-1}\right)$. Each treatment consisted of seven replicates and experimental unit was one explant per vessel. Subculturing was done by transferring the micro-shoots to fresh shoot induction medium.

The shoot tips, cotyledonary nodes explants which showed good response for shoot multiplication were then used in the further experiments to enhance multiple shoot production. After assessing the effect of different cytokinins and auxins on shoot induction and multiplication, its effect in combination with other basal media like WPM and $\mathrm{B} 5$ were tested.

\section{Rooting of shoots and transfer of plantlets to soil}

The microshoots of $4-5 \mathrm{~cm}$ length were dissected from proliferated shoot cultures. Rooting of elongated shoots were carried out on full and half strength MS medium with and without different concentrations of Calcium nitrate and Calcium panthothenate including IBA, IAA either individually or in combinations and was compared to the control (shoots in MS medium without hormonal supply). After 6-8 weeks of inoculation, rooting frequency and the number of roots were recorded. Rooted plantlets were removed from culture tubes and washed thoroughly in sterile distilled water to remove all traces of the medium attached to the roots and were transplanted to plastic pots containing a mixture of autoclaved soil, peat moss, and soilrite (2:1:1) subsequently to field conditions.

\section{Statistics}

Each culture tube with one shoot explants was considered as one replicate. Each treatment in each set of experiments consists of 20 replicates and each experiment was repeated three times. Standard error of means was calculated in each experiment. The data was statistically analyzed using one way analysis of variance (ANOVA) and means were compared using the Duncan's multiple range test (DMRT) at the $0.05 \%$ level of significance

\section{Results and discussion}

\section{Raising of aseptic seedlings}

In the present study, we initially looked for the seed germination capabilities of $S$. febrifuga under in vivo and In vitro conditions. As expected, our results clearly demonstrated that percentage of germination was poor in vivo conditions compared to In vitro conditions. The reason might be loss of moisture content in the seeds of in vivo. More importantly, we noticed the seedlings raised under in vivo suffered from root rot and were found to be unhealthy. No alternative mode of multiplication is available to propagate and to conserve genetic stock of this medicinal plant. Hence, tissue culture of Soymida febrifuga offers an effective alternative method for its rapid multiplication. An emphasis was laid on various factors such as sterilants, type of media, hormones, sucrose concentration and seed viability (Unpublished) influencing In vitro seed germination which is used as a starting material for In vitro morphogenic studies. In vitro seed germination Soymida febrifuga commenced on the $4^{\text {th }}$ day. Healthy aseptic seedlings of with appropriate root system was found effective and best on MS full strength medium containing $1 \%$ and $1.5 \%$ sucrose medium (Fig. 1A) unfortified with growth hormones compared to MS half/quarter strength/WPM/ B5 media.

\section{Direct shoot regeneration from seedling explants}

Mature tree explants are relatively poor in regeneration (Hakanson and Pooler, 2000). The same observation was noticed with mature nodal explants of S. febrifuga (Chiruvella $e t$ al., 2011). Hence the shoot regeneration efficiency of Soymida febrifuga was improved by using morphogenic juvenile explants, as the seedling explants are more responsive than explants derived from mature trees and 
520

many tree species have been successfully propagated from seedlings for micropropagation (Le Roux et al., 1992; Villarreal and Rojas, 1996). Moreover the use of intact seedlings for plant regeneration studies by passes the step of explant preparation due to the fact that these are free of endophytic microbes. Besides, the additional advantage of using seedling derived tissues for micropropagation is essentially due to the fact that these are free from phenolic compounds whose accumulation inhibit organogenesis in more mature trees (Thorpe, 1982).

Next, we examined using juvenile explants from 15 day old aseptic seedlings. Shoot tips, cotyledonary node, cotyledon, leaves, hypocotyl and root segments of aseptic seedling were excised and inoculated on to various shoot multiplication media. Shoot induction was found only with cotyledonary node and shoot tip while other explants viz., cotyledon, In vitro leaves and root segments showed the formation of morphogenic callus (Unpublished). Hence, further studies on direct shoot multiplication were carried out using shoot tip and cotyledonary node.

\section{Effect of plant growth regulators on shoot multiplication from cotyledonary nodes}

Cotyledonary nodes on MS basal medium without growth regulators formed no shoots. Initial experiments on culture initiation and establishment were tried with BA. Experiments on shoot organogenesis using various concentrations and combinations of BA and auxins (NAA and IAA) revealed that $\mathrm{BA}$ alone was sufficient to trigger the growth of the shoots from cotyledonary node explants. Addition of auxins (NAA and IAA) to the cytokinin enriched medium improved the shoot multiplication without callusing.

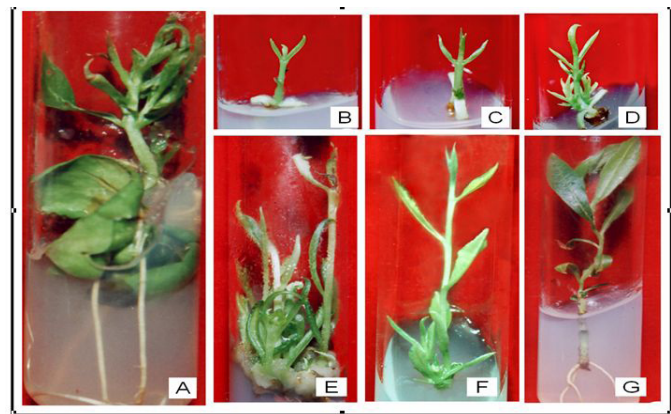

Fig. 1. Seed germination and Direct shoot regeneration from cotyledonary node of Soymida febrifuga; (A) Raising of aseptic seedling on MS basal solid medium; (B) Single shoot initiation on MS medium with $3.0 \mathrm{mg} \mathrm{l}^{-1} \mathrm{BA}$ after 5 days; Shoot proliferation on the same above medium after 10 days (C) after 15 days (D); (E) Multiple shoot production on the same medium after 5 weeks; (F) Elongated shoot on medium containing 2.0 $\mathrm{mg} \mathrm{l}^{-1} \mathrm{BA}$ and $2.0 \mathrm{mg} \mathrm{l}^{-1} \mathrm{Kn}$ after 4 weeks; (G) In vitro rooting of $S$. febrifuga on MS half strength medium containing $556 \mathrm{mg}$ $l^{-1} \mathrm{Ca}(\mathrm{NO} 3) 2+1.0 \mathrm{mg} \mathrm{l}-l$ calcium pantothenate $+2.0 \mathrm{mg} \mathrm{l}^{-1}$ IBA+2.0 $\mathrm{mgl}^{-1}$ IAA after 7 weeks
Therefore in further experiments auxins were incorporated in the culture medium. Cotyledonary nodes produced maximum number (16.6) of multiple shoots (Tab. 1) on MS medium with $3.0 \mathrm{mg} \mathrm{l}^{-1} \mathrm{BA}$ (Fig. 1B-E) and showed high frequency $(80.5 \%)$ of regeneration. Clusters of 10-12 shoot buds were differentiated in the axils of cotyledonary node after 12 days of inoculation. Shoots developed from the already existing buds on cotyledonary node explants grew first $(1.0-3.0 \mathrm{~cm})$ followed by the shoots developed from the differentiated buds in a period of 4 weeks. Cotyledonary nodes showed a decrease in shoot number and length with increasing concentrations of $\mathrm{BA}$ (Tab. 1). Further, cotyledonary nodes produced callus at low concentrations of BA $\left(0.1-1.0 \mathrm{mgl}^{-1}\right)$ but this was negligible at high concentrations of $\mathrm{BA}\left(>2.0 \mathrm{mgl}^{-1}\right)$.

Tab. 1. Effect of plant growth regulators on shoot initiation from cotyledonary seedling explants of Soymida febrifuga (after 8 weeks)

\begin{tabular}{|c|c|c|c|c|c|c|}
\hline \multicolumn{4}{|c|}{ PGR (mg-l) } & \multicolumn{3}{|c|}{ Cotyledonary node } \\
\hline BA & $\mathrm{KN}$ & NAA & IAA & $\begin{array}{c}\% \text { of } \\
\text { regeneration }\end{array}$ & $\begin{array}{c}\text { Mean no of } \\
\text { shoots / explant }\end{array}$ & $\begin{array}{l}\text { Mean length } \\
\text { of the shoot }\end{array}$ \\
\hline 2.0 & & & & $66.8 \pm 0.65^{\mathrm{fg}}$ & $8.3 \pm 0.30^{\prime}$ & $4.1 \pm 0.15^{\mathrm{def}}$ \\
\hline 2.0 & & & 0.2 & $58.3 \pm 0.92^{d}$ & $7.5 \pm 0.17^{\mathrm{ij}}$ & $3.4 \pm 0.18^{\mathrm{cde}}$ \\
\hline 2.0 & & 0.2 & & $69.2 \pm 0.24$ ghi & $5.8 \pm 0.17^{\text {gh }}$ & $3.8 \pm 0.33$ def \\
\hline 3.0 & & & & $80.5 \pm 0.62^{j}$ & $16.6 \pm 0.33^{1}$ & $3.4 \pm 0.31^{\text {cde }}$ \\
\hline 3.0 & & 0.2 & & $72.1 \pm 1.08^{i}$ & $12.4 \pm 0.35^{k}$ & $3.0 \pm 0.33$ abcd \\
\hline 3.0 & & & 0.2 & $67.3 \pm 0.67^{\mathrm{fg}}$ & $6.8 \pm 0.11^{\mathrm{hi}}$ & $4.7 \pm 0.31$ ef \\
\hline 5.0 & & & & $63.1 \pm 0.87^{\mathrm{e}}$ & $4.8 \pm 0.14^{\mathrm{fg}}$ & $3.3 \pm 0.29^{\text {bcde }}$ \\
\hline 5.0 & & 0.2 & & $65.3 \pm 0.84$ ef & $3.7 \pm 0.16^{\mathrm{cde}}$ & $2.2 \pm 0.27^{\mathrm{abc}}$ \\
\hline 5.0 & & & 0.2 & $45.0 \pm 0.86^{c}$ & $2.6 \pm 0.18 \mathrm{abc}$ & $1.7 \pm 0.2^{\mathrm{ab}}$ \\
\hline & 2.0 & & & $55.6 \pm 0.67^{d}$ & $4.4 \pm 0.17^{\text {def }}$ & $5.3 \pm 0.42^{f}$ \\
\hline & 2.0 & 0.2 & & $67.5 \pm 0.76^{\mathrm{fgh}}$ & $5.3 \pm 0.21^{\mathrm{fg}}$ & $3.8 \pm 0.18^{\mathrm{def}}$ \\
\hline & 3.0 & & & $38.5 \pm 0.56^{b}$ & $3.6 \pm 0.29^{b c d e}$ & $4.2 \pm 0.18$ def \\
\hline & 3.0 & 0.2 & & $43.1 \pm 0.60^{c}$ & $4.5 \pm 0.2^{\mathrm{def}}$ & $3.7 \pm 0.21^{\text {cde }}$ \\
\hline 2.0 & 1.0 & & & $72.0 \pm 0.48^{i}$ & $2.4 \pm 0.19^{\mathrm{ab}}$ & $4.0 \pm 0.14^{\mathrm{def}}$ \\
\hline 2.0 & 2.0 & & & $65.9 \pm 0.58^{\text {efg }}$ & $4.7 \pm 0.34^{\mathrm{efg}}$ & $4.2 \pm 0.41^{\mathrm{def}}$ \\
\hline 2.0 & 3.0 & & & $70.8 \pm 0.38^{\text {hi }}$ & $3.4 \pm 0.19^{\mathrm{ab}}$ & $3.7 \pm 0.36^{\text {cde }}$ \\
\hline 3.0 & 1.0 & & & $54.8 \pm 0.20^{d}$ & $2.5 \pm 0.34$ & $3.1 \pm 0.50^{\mathrm{abcd}}$ \\
\hline 3.0 & 2.0 & & & $37.5 \pm 0.76^{b}$ & $5.3 \pm 0.31^{\mathrm{fg}}$ & $2.7 \pm 0.39 \mathrm{abcd}$ \\
\hline 3.0 & 3.0 & & & $18.8 \pm 0.37^{a}$ & $2.2 \pm 0.17^{a}$ & $1.6 \pm 0.24^{a}$ \\
\hline
\end{tabular}

Values represented are the mean of 20 replicates. Mean values having the same letter in each column do not differ significantly at $\mathrm{P} \leq 0.05$ (Tukey Test)

BA at $3.0 \mathrm{mgl}^{-1}$ along with $0.2 \mathrm{mgl}^{-1} \mathrm{NAA}$ did not show marked effect on shoot number and shoot length when compared with BA alone. BA in combination with NAA produced shoots having thick leaves and fleshy internodes. $\mathrm{BA}$ in combination with IAA or $\mathrm{Kn}$ was found ineffective in terms of shoot multiplication when compared to BA alone or in combination with NAA. The NAA enabled better regeneration than IAA. Kinetin alone was less effective when compared to BA in combination. BA $(3.0 \mathrm{mg}$ 
$\left.\mathrm{l}^{-1}\right)$ in combination with $\mathrm{Kn}\left(2.0 \mathrm{mgl}^{-1}\right)$ showed 5.3 mean number of shoots (Tab. 1). $2.0 \mathrm{mgl}^{-1} \mathrm{BA}$ in combination with $1.0 \mathrm{mg} \mathrm{l}^{-1} \mathrm{Kn}$ showed $72.8 \%$ frequency of regeneration. Kn at $2.0 \mathrm{mgl}^{-1}$ in combination with $0.2 \mathrm{mgl}^{-1} \mathrm{NAA}$ produced maximum (5.3) shoots with mean shoot length of $3.8 \mathrm{~cm}$ with $67.3 \%$ of frequency of regeneration. Maximum mean length of the shoots $(4.2 \mathrm{~cm})$ was observed in medium containing BA $\left(2.0 \mathrm{mgl}^{-1}\right)$ in combination with $\mathrm{Kn}\left(2.0 \mathrm{mgl}^{-1}\right)$ (Fig. 1F).

$\mathrm{BA}$ at $3.0 \mathrm{mg} \mathrm{l}^{-1}$ on other basal media viz., WPM and B5 did not show marked influence on shoot multiplication and frequency of regeneration (data not shown). Cotyledonary nodes responded better on MS medium than on other media tested in the present study (Tab. 1). Many woody species have been propagated successfully by In vitro shoot proliferation from cotyledonary node explants (Naik et al., 2000; Pradhan et al., 1998; Seema and Jaiswal 2002) and the superior response was reported by Gupta et al. (1997); Bhatt and Dhar (2000).

\section{Effect of plant growth regulators on shoot multiplication from shoot tip explants}

Shoot tip cultures are generally used to get genetically identical plants (Murashige, 1974). When shoot tips of aseptic seedlings measuring $0.5-1.0 \mathrm{~cm}$ in length were inoculated vertically as well as horizontally on MS medium supplemented with $\mathrm{BA}$ alone or in combination $\mathrm{KN}$ / NAA/IAA, shoots were regenerated directly on explants placed only in the vertical orientations. However, the percentage of shoot regeneration, the number of shoots per explant and the length of the shoot varied significantly (Tab. 2).Maximum frequency of regeneration, number of shoots per explant and the shoot length were achieved when the explants were inoculated vertically than horizontally. Degree of basal callus formation was found to be less in vertically placed explants when compared to the explants placed horizontally.

BA $\left(2.0 \mathrm{mgl}^{-1}\right)$ was found to be effective in inducing maximum number of multiple shoots (7.9) with shoot length of $5.2 \mathrm{~cm}$ (Fig. $2 \mathrm{~A}-\mathrm{F}$ ) and maximum frequency of regeneration $(80.9 \%)$. Increased or decreased BA concentrations $\left(<2.0 \mathrm{mgl}^{-1}>\right)$ showed reduction in frequency of regeneration, shoot number and shoot length. Shoot tips when cultured in MS medium containing $2.0 \mathrm{mgl}^{-1} \mathrm{BA}+$ $1.0 \mathrm{mgl}^{-1} \mathrm{Kn}$ have shown maximum frequency of regeneration $(83.5 \%)$ with 6.1 mean number of shoots and mean shoot length $(5.0 \mathrm{~cm})($ Fig. $2 \mathrm{H}, \mathrm{I})$ than $\mathrm{Kn}$ alone or in combination with auxins. Kinetin $(2.0 \mathrm{mgl}-\mathrm{l})$ alone produced 2.8 shoots/explant with a shoot length of $4.7 \mathrm{~cm}$. MS medium containing Kn $\left(3.0 \mathrm{mgl}^{-1}\right)+\mathrm{NAA}\left(0.2 \mathrm{mgl}^{-1}\right)$ showed a $58.1 \%$ of regeneration (Tab. 2).

BA $\left(2.0 \mathrm{mgl}^{-1}\right)$ along with NAA $\left(0.2 \mathrm{mgl}^{-1}\right)($ Fig. 2$)$ was efficient than IAA in producing maximum number of shoots/explant (4.8) with maximum frequency of regeneration (77.3\%) and shoot length of $4.4 \mathrm{~cm}$.

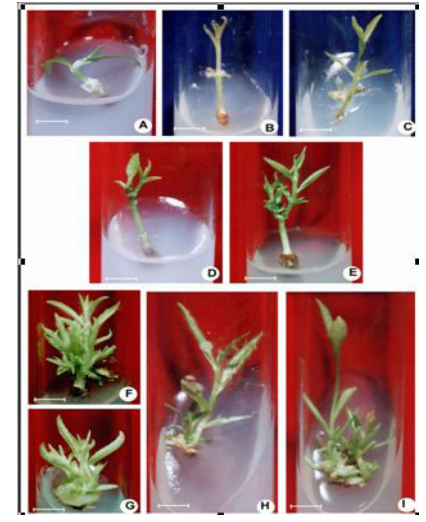

Fig. 2. Direct shoot regeneration from shoot tip of Soymida febrifuga; (A) Single shoot initiation on MS medium supplemented with $2.0 \mathrm{mg} \mathrm{l}^{-1} \mathrm{BA}$ after one week; Multiple shoot proliferation on the above medium after 2 weeks (B) 3 weeks (C) 4 weeks (D) 5 weeks $(F) ;(G)$ Production of multiple shoots with basal callus on medium containing $2.0 \mathrm{mg} \mathrm{l}^{-1} \mathrm{BA}+0.2 \mathrm{mg} \mathrm{l}^{-1} \mathrm{NAA}$ after 3 weeks; (H, I) Shoot elongation on medium containing $2.0 \mathrm{mg}$ $\mathrm{l}^{-1} \mathrm{BA}+1.0 \mathrm{mg} \mathrm{l}^{-1} \mathrm{Kn}$ after 3 weeks (H) 5 weeks (I)

Tab. 2. Effect of plant growth regulators on shoot initiation from shoot tip seedling explants of Soymida febrifuga (after 8 weeks)

\begin{tabular}{|c|c|c|c|c|c|c|}
\hline \multicolumn{4}{|c|}{ PGR (mg-l) } & \multicolumn{3}{|c|}{ Cotyledonary node } \\
\hline BA & $\mathrm{KN}$ & NAA & IAA & $\begin{array}{c}\% \text { of } \\
\text { regeneration }\end{array}$ & $\begin{array}{c}\text { Mean no } \\
\text { of shoots } \\
\text { / explant }\end{array}$ & $\begin{array}{l}\text { Mean length } \\
\text { of the shoot }\end{array}$ \\
\hline 2.0 & & & & $80.0 \pm 0.58^{k}$ & $7.9 \pm 0.16^{k}$ & $5.2 \pm 0.17^{\mathrm{h}}$ \\
\hline 2.0 & & & 0.2 & $76.2 \pm 0.92^{j}$ & $4.0 \pm 0.23^{\mathrm{gh}}$ & $3.5 \pm 0.16^{c}$ \\
\hline 2.0 & & 0.2 & & $77.3 \pm 0.95 \mathrm{j}^{\mathrm{k}}$ & $4.8 \pm 0.24$ & $4.4 \pm 0.10^{\text {efg }}$ \\
\hline 3.0 & & & & $56.1 \pm 0.87^{\mathrm{cfg}}$ & $4.2 \pm 0.17^{\text {ghi }}$ & $4.2 \pm 0.10^{\text {def }}$ \\
\hline 3.0 & & 0.2 & & $60.3 \pm 0.76^{\mathrm{h}}$ & $3.8 \pm 0.10^{\text {cefg }}$ & $3.8 \pm 0.11^{\mathrm{cde}}$ \\
\hline 3.0 & & & 0.2 & $53.3 \pm 0.88^{\text {ef }}$ & $2.8 \pm 0.17^{\mathrm{cd}}$ & $2.7 \pm 0.12^{\mathrm{b}}$ \\
\hline 5.0 & & & & $42.8 \pm 0.75^{c}$ & $2.7 \pm 0.18^{\mathrm{cd}}$ & $3.6 \pm 0.14^{\mathrm{cd}}$ \\
\hline 5.0 & & 0.2 & & $38.1 \pm 0.59^{b}$ & $2.2 \pm 0.12^{\mathrm{abc}}$ & $2.8 \pm 0.21^{\mathrm{b}}$ \\
\hline 5.0 & & & 0.2 & $60.2 \pm 0.68^{\mathrm{h}}$ & $1.6 \pm 0.17^{\mathrm{a}}$ & $1.8 \pm 0.18^{a}$ \\
\hline & 2.0 & & & $55.0 \pm 0.52^{e^{\mathrm{fg} g}}$ & $2.8 \pm 0.15^{\mathrm{cd}}$ & $4.7 \pm 0.11^{\mathrm{fgh}}$ \\
\hline & 2.0 & 0.2 & & $47.1 \pm 0.60^{d}$ & $2.3 \pm 0.09 \mathrm{ac}$ & $4.2 \pm 0.11^{\mathrm{def}}$ \\
\hline & 3.0 & & & $52.8 \pm 0.60^{\mathrm{e}}$ & $2.0 \pm 0.15^{\mathrm{ab}}$ & $3.7 \pm 0.05^{\mathrm{cde}}$ \\
\hline & 3.0 & 0.2 & & $58.1 \pm 0.60^{\mathrm{gh}}$ & $1.8 \pm 0.11^{\mathrm{a}}$ & $2.8 \pm 0.13^{\mathrm{b}}$ \\
\hline 2.0 & 1.0 & & & $83.5 \pm 0.7^{6}$ & $6.1 \pm 0.22^{i}$ & $5.0 \pm 0.23^{g h}$ \\
\hline 2.0 & 2.0 & & & $76.1 \pm 0.48^{j}$ & $4.7 \pm 0.14^{\mathrm{hi}}$ & $4.5 \pm 0.13^{\mathrm{fg}}$ \\
\hline 2.0 & 3.0 & & & $68.1 \pm 0.64^{i}$ & $3.2 \pm 0.14^{\mathrm{def}}$ & $3.3 \pm 0.14^{\mathrm{bc}}$ \\
\hline 3.0 & 1.0 & & & $56.5 \pm 0.43^{\text {fg }}$ & $4.0 \pm 0.11^{\mathrm{ghi}}$ & $4.3 \pm 0.08^{\text {ef }}$ \\
\hline 3.0 & 2.0 & & & $40.0 \pm 0.58^{b c}$ & $3.1 \pm 0.10^{\text {de }}$ & $3.8 \pm 0.11^{\text {cde }}$ \\
\hline 3.0 & 3.0 & & & $28.1 \pm 0.48^{\mathrm{a}}$ & $2.2 \pm 0.08^{\mathrm{abc}}$ & $1.2 \pm 0.09^{a}$ \\
\hline
\end{tabular}

Values represented are the mean of 20 replicates. Mean values having the same letter in each column do not differ significantly at $\mathrm{P} \leq 0.05$ (Tukey Test).

The response of shoot tip explants in terms of mean shoot number was comparatively lesser than those of cotyledonary node and mature nodal explants (Chiruvella $e t$ al., 2011). Shoot tip explants have been selected for mi- 
522

cropropagation for the induction of multiple shoots in several medicinal plants which include Gymnema sylvestre (Komalavalli and Rao, 2000), Asclepias curassavica (Karpagam and Rao, 2003) and Hemidesmus indicus (Neeta et al., 2003), Taxus baccata (Nandi et al., 1997), Yucca aloifolia (Alla and Staden, 1997) and Anicistrocladus abbreviatus (Bringmann et al., 1999). Shoot tips from seedlings were successfully cultured on MS medium supplemented with BA in Swietenia macrophylla (Maruyama and Ishii, 1999). The potentiality of shoot bud regeneration of shoot tip explants was less than that of cotyledonary node and nodal explants based on the percentage of response, number of shoots formed and length of shoots (Tab. 2).

\section{Rooting and field establishment}

Elongated shoots obtained from cotyledonary node and shoot tip explants when subjected to rooting recaptitulated shoot tip necrosis as reported recently by our group (Chiruvella et al., 2011; Kulkarni and Souza, 2000). Shoot tip necrosis is a phenomenon in which the terminal portion of the shoot becomes dark and dies. Our results demonstrate that micropropagation of this tree is seriously hampered by apical necrosis of shoots and leaves in culture causing severe loss of cultures as reported (Srivasatva and Joshi, 2013; Chiruvella et al., 2011; Bairu et al., 2009; Thakur and Kanwar, 2008; Martin, 2007; Kulkarni and Souza, 2000). We could easily prevent necrosis by supplying calcium in the form of calcium nitrate and calcium pantothenate. Calcium addition to the MS medium not only favoured the control of shoot tip necrosis but also promoted In vitro rooting (Tab. 3, Fig. $1 \mathrm{H}$ ) (Chiruvella et al., 2011). Hence, MS medium containing IBA fortified with calcium supply in the form of calcium nitrate individually or in combination with calcium pantothenate was found to be crucial and essential for rooting of micropropagated shoots (Fig. 1H, Tab. 3).

Efficient rooting of In vitro regenerated plants and subsequent field establishment is the last and crucial stage of rapid clonal propagation. Pots containing In vitro derived plantlets were kept in the culture room temperature and pots were covered with polythene bags to maintain high humidity and kept in mist chamber covered with coir mat. Survival of In vitro plants after planting is largely dependent on the components of the potting media. In the present study, vermiculite: soil (1:1) was found suitable for highest survival of plants (Fig. 3). The plants propagated In vitro now were well established and able to sustain easily on their own after transfer to the field condition and showed normal behaviour of growth with similar morphological characters. After one week, by which time a fresh leaf appeared from the potted plants, were transferred to green house and then transferred to field condition. 70$85 \%$ of regenerated plants were successfully acclimatized to natural environment (Fig. 3). In vitro derived plantlets were morphologically similar to in vivo plants.

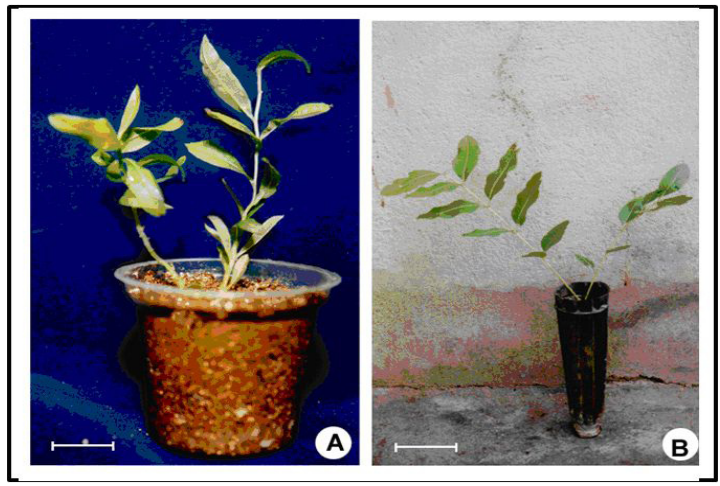

Fig. 3. Hardening of Soymida febrifuga; (A) Micropropagated plantlet growing in a plastic cup after 2 weeks; (B) Transplanted tissue cultured plant grown in a pot after 6 weeks

Tab. 3. In vitro rooting of Soymida febrifuga (after 5 weeks)

\begin{tabular}{|c|c|c|c|c|c|}
\hline CAN & CAP & IBA & $\begin{array}{l}\text { Frequency of } \\
\text { regeneration }\end{array}$ & $\begin{array}{c}\text { Mean number } \\
\text { of roots }\end{array}$ & $\begin{array}{c}\text { Mean length } \\
\text { of the root }\end{array}$ \\
\hline 556 & & 1.0 & $35.4 \pm 0.58^{d}$ & $2.1 \pm 0.08^{c}$ & $4.4 \pm 0.13^{f}$ \\
\hline 556 & & 2.0 & $47.6 \pm 0.76^{\mathrm{f}}$ & $4.1 \pm 0.09^{\mathrm{e}}$ & $3.5 \pm 0.10^{\mathrm{d}}$ \\
\hline 556 & & & $22.8 \pm 0.59^{b}$ & $1.4 \pm 0.08^{\mathrm{a}}$ & $12.5 \pm 0.15^{k}$ \\
\hline 556 & & & $18.6 \pm 0.36^{a}$ & $1.1 \pm 0.10^{\mathrm{a}}$ & $11.9 \pm 0.19^{k}$ \\
\hline 834 & & 1.0 & $40.4 \pm 0.37^{e}$ & $3.0 \pm 0.07^{\mathrm{d}}$ & $3.3 \pm 0.13^{d}$ \\
\hline 834 & & 2.0 & $49.0 \pm 0.33^{f}$ & $4.0 \pm 0.07^{\mathrm{de}}$ & $2.3 \pm 0.12^{\mathrm{b}}$ \\
\hline 834 & & & - & - & - \\
\hline 834 & & & - & - & - \\
\hline 556 & 1.0 & 2.0 & $91.2 \pm 0.49^{i}$ & $4.8 \pm 0.18^{f}$ & $10.8 \pm 0.24^{i}$ \\
\hline 556 & 1.0 & 2.0 & $95.0 \pm 0.45^{k}$ & $5.1 \pm 0.10^{\mathrm{g}}$ & $11.2 \pm 0.19^{j}$ \\
\hline 834 & 1.0 & 2.0 & $75.8 \pm 0.38$ & $3.9 \pm 0.12^{\mathrm{de}}$ & $6.6 \pm 0.21^{g}$ \\
\hline 834 & 1.0 & 2.0 & $81.9 \pm 0.38^{i}$ & $4.1 \pm 0.09^{\mathrm{e}}$ & $8.0 \pm 0.19^{\mathrm{h}}$ \\
\hline 556 & 1.0 & 2.0 & $78.0 \pm 0.33^{h}$ & $6.0 \pm 0.11^{\mathrm{h}}$ & $3.9 \pm 0.10^{\mathrm{e}}$ \\
\hline 556 & 1.0 & 2.0 & $57.0 \pm 0.44^{\mathrm{g}}$ & $3.5 \pm 0.09^{d}$ & $2.5 \pm 0.23^{b c}$ \\
\hline 834 & 1.0 & 2.0 & $48.9 \pm 0.64^{\mathrm{f}}$ & $2.5 \pm 0.06^{c}$ & $2.0 \pm 0.14^{b}$ \\
\hline 834 & 1.0 & 2.0 & $32.1 \pm 0.34^{c}$ & $1.6 \pm 0.10^{\mathrm{b}}$ & $1.5 \pm 0.09^{\mathrm{a}}$ \\
\hline
\end{tabular}

Values represented above are the means of 20 replicates. Mean values having the same letter in each column do not differ significantly at $\mathrm{P} \leq 0.05$ (Tukey Test)..

\section{Conclusion}

We report an efficient protocol for micropropagation of the endemic tree of Rajasthan S. febrifuga. This protocol provides a successful and rapid technique that can be used for ex situ conservation. As a part of domestication strategy, these plants can be grown and further cultivated in fields. The application of this protocol can help minimize the pressure on wild populations and contribute to the conservation of valuable flora of the Western Ghats.

\section{Acknowledgements}

We sincerely thank Dept. of Botany, SV University, Tirupati for providing us the chemicals and facilities. We highly appreciate our lab members especially Dr. Gayathri 
Dampuri for critical reading of the manuscript. KKC is supported financially by Dep. of Botany, SV University.

\section{Author contributions}

Conceived and designed the experiments: KKC, AM, GRG. Performed the experiments: KKC. Analyzed the data: KKC, AM, GRG. Wrote the paper: KKC, AM, GRG.

\section{References}

Ahuja MR (1993). Micropropagation of Woody Plants., Kluwer Academic Publi Dordrecht, Netherlands p. 153.

Alla HA, Staden JV (1997). Micropropagation and establishment of Yucca aloifolia. Plant Cell Tiss Org Cult 48:209213.

Srivastava A, Joshi AG (2013). Control of Shoot Tip Necrosis in Shoot Cultures of Portulaca grandiflora Hook. Not Sci Biol 5(1):45-49.

Anonymous (1952). The Wealth of India. Public Info Directorate CSIR, New Delhi p. 9:471-472.

Bairu MW, Jain N, Stirk WA, Dolezal K, Van Staden J (2009). Solving the problem of shoot-tip necrosis in Harpagophytum procumbens by changing the cytokinin types, calcium and boron concentrations in the medium. South African J Bot 75:122-127.

Bhatt ID, Dhar U (2000) Combined effect of cytokinins on multiple shoot production from cotyledonary node explants on Baubinia vahlii. Plant Cell Tiss Org Cult 62:79-83.

Bonga JM (1987). Clonal Propagation of Mature Trees: Problems and Possible Solutions. Martinus Nijhoff Publi, Dordrecht p. 249.

Bringmann G, Rischer J, Schlaner J, Assi LK (1999). In vitro propagation of Ancistrocladus abbreviatus Airy Shaw (Ancistrocladaceae). Plant Cell Tiss Org Cult 57:71-73.

Chopra RN, Nayar SL,Chopra IC (1956). Glossary of Indian medicinal plants. CSIR, New Delhi p. 32.

Diwan PV, Singh AK (1993). Anti-inflammatory activity of Soymida febrifuga (Mansa rohini) in rats and mice from bark powders. Phytother Res 7(3):255-256.

Gupta SK, Srivastava AK, Singh PK, Tuh R (1997). In vitro proliferation of shoots and regeneration of cotton. Plant Cell Tiss Org Cult 51:149-152.

Karpagam N, Rao MV (2003). In vitro Clonal Multiplication of Asclepias curassavica L: A Multipurpose Medicinal Herb. Nat. Symp. on Emerging Trends Indian Med. Plants p. 20.

Kirtikar KR, Basu BD (2003). Indian Medicinal Plants. Oriental Enterpri,Dehradun p. 778-780.

Chiruvella KK, Mohammed A, Dampuri G, Ghanta RG, Raghavan SC (2007). Phytochemical and antimicrobial studies of methyl angolensate and luteolin-7-0-glucoside isolated from callus cultures of Soymida febrifuga. Int J Biomedical Sci 3:269-278.
Chiruvella KK, Kari V, Choudhary B, Nambiar M, Ghanta RG, Raghavan SC (2008). Methyl Angolensate, a Natural Tetranortriterpenoid Induces Intrinsic Apoptotic Pathway in Leukemic Cells, FEBS Letters 582:4066-4076.

Chiruvella KK, Mohammed A, Dampuri G, Ghanta RG (2011). In vitro Shoot Regeneration and Control of Shoot Tip Necrosis in Tissue Cultures of Soymida febrifuga (Roxb.) A. Juss. Plant Tissue Cult. \& Biotech. 21(1):11-25.

Komalavalli N, Rao MV (2000) In vitro micropropagation of Gymnema sylvestre- A multipurpose medicinal plant.Plant Cell Tiss Org Cult 61:97-105.

Kulkarni KR, D'Souza L (2000) Control of shoot tip necrosis in Butea monosperma. Curr Sci. 78:125-126.

LeRoux JJ, Brown NAC, Leivers S (1992). Micropropagation of Aspalathus linearis through bud multiplication. Plant Cell Tiss Org Cult 28:225-227.

Martin KP, Zhang C, Slater A, Madassery J (2007). Control of shoot necrosis and plant death during micro propagation of banana and plantains (Musa spp.). Plant Cell Tiss Org Cult 88:51-59.

Maruyama E, Ishi K (1999) Somatic Embryogenesis in Big-Leaf Mahogany (Swietenia macrophylla King), Kluwer Academic Publi Dordrecht p. 45-62.

Naik SK, Pattnaik S, Chand PK (2000). High frequency axillary shoot proliferation and plant regeneration from cotyledonary nodes of pomegranate (Punica granatum L.). Sci Hort 85:261-263.

Nandi SR, Rikhari HC, Nadeen M, Palni LMS (1997) Clonal propagation of Taxus baccata L: Himalayan asset under threat. Physiol Mol Biol Plants 3:15-24.

Neeta M, Pratibha M, Datta SK, Shanta M (2003) Improvement in clonal propagation of Hemidesmus indicus R.Br. through adenine sulphate. J Plant Biotechnol 5:239-244.

Pradhan C, Kar S, Pattnaik S, Chand PK (1998). Propagation of Dalbergia sissoo Roxb. through in vitro shoot proliferation from cotyledonary nodes. Plant Cell Rep 18:122-126.

Simonsen HT, Nordskjold JB, Smitt UW, Nyman U, Palpu P, Joshi P, Varughese GG (2001). In vitro screening of Indian medicinal plants for antiplasmodial activity. J Ethnopharmacol. 74:195-204.

Seema P and Jaiswal VS (2002). Micropropagation of Terminalia arjuna Roxb.from cotyledonary nodes. Ind. J Exp Biol 40:950-953.

Thakur A and Kanwar JS (2008). Micropropagation of 'Wildpear' Pyrus pyrifolia (Burm F.) Nakai. II Induction of Rooting. Not Bot Hoti Agrobo 36(2):104-111.

Thorpe TA (1982) Carbohydrate Utilization and Metabolism. 1, Martinus Nijhoff, Hague 1:325-368.

Villarreal ML and Rojas G (1996) In vitro propagation of Mimosa tenuiflora (Willd.) Poiret, a Mexican medicinal tree. Plant Cell Rep 16:80-82.

Yoganarasimhan SN (1996). Medicinal plants of India Vol. 1 Interline Publishing Pvt Ltd Bangalore p. 1. 